\title{
Pallid Sturgeon Scaphirhynchus albus
}

Habitat Preference: Large turbid rivers with rocky or sandy bottoms. Prefer naturally meandering rivers with channels, backwater, diversity in water depths and flow velocities.

\section{Threats:}

- Human modifications of river habitat through dam construction and development for commercial navigation.

- Dams isolate populations.

- Altered water flow regimes interfere with

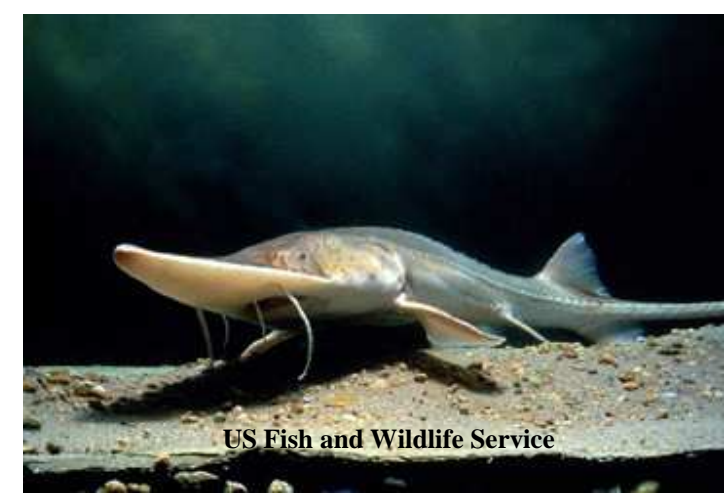
spawning.

- Reduction in turbidity due to presence of mainstem dams has altered the aquatic ecosystem of the Missouri River along lowa to the detriment of pallid sturgeon and preferred prey items (minnows of the genus Macrhybopsis and Hybognathus).

- Prevents movement to spawning habitat.

- Channel modifications (channelization; channel training structures) reduce habitat complexity (e.g., eliminate sandbars) and suitability for use by pallid sturgeon and their preferred prey items (minnows of the genus Macrhybopsis and Hybognathus).

- Reduced habitat complexity of altered rivers lead to hybridization with the more common shovelnose sturgeon raising the possibility of genetic swamping of the remaining populations of pallid sturgeon in lowa waters.

\section{Appropriate Practices:}

- Mimic a natural hydrologic flow in areas with flow controlled from dams.

- Limit new construction of dams in major rivers that harbor pallid sturgeon populations.

- Avoid additional channel modifications for commercial navigation; allow, to the extent possible, natural river processes (e.g., meandering, sandbar formation) to occur. 